\title{
EFFECT OF SPRINKLER IRRIGATION AND LAND PREPARATION SYSTEMS ON SOYBEAN CROP PRODUCTION IN CLAYEY SOIL
}

\author{
T. M. Attafy ${ }^{1}$, W. F. EL Metwally ${ }^{1}$ and A. M. Okasha ${ }^{2}$
}

\section{ABSTRACT}

Properirrigation systems essential for maximum soybean production and becomes even more important withideal land preparation system. A field study was conducted at the research farm of Rice Mechanization Center (RMC), Meet El-Deeba, Kafr El-Sheikh Governorate, Egypt during the summer seasons 2015 and 2016.The aim of the present research was to study the effect of sprinkler irrigation and land preparation systems on Soybean productivity.The sprinkler irrigation system was studiedatthree different distances between sprinklers; $D 1=9 m$ (50\% diameter of throw ), $D 2=10.8 \mathrm{~m}$ (60\% diameter of throw) and $\mathrm{D} 3=14.5 \mathrm{~m}$ (80\% diameter of throw ) and three different values of applied water;60,80 and 100\% from crop evapotranspiration (ETc).The land preparation systems were: LP1(Chiseling twice + leveling),LP2 (Chiseling one pass + rotary two passes + leveling) and LP3 (Moldboard one pass + rotary one pass + leveling).

The experimental results revealed that:

- LP3 treatment gave the least soil bulk density for three layers comparing with other land preparation systems. Also, it gave the average of lowest infiltration rate value $(2 \mathrm{~mm} / \mathrm{h})$ that obtained after 110 min of infiltration time.

- The highest value of soil penetration resistance was $13.02 \mathrm{~kg} / \mathrm{cm}^{2}$ which obtained at LP2treatment while the lowest value was $11.83 \mathrm{~kg} / \mathrm{cm}^{2}$ at LP3 treatment.

- Increasing distances between sprinklers from 9 to $14.5 \mathrm{~m}$ tended to decrease Christiansen uniformity coefficient $\left(C_{u}\right)$ by $11.14 \%$ and distribution uniformity $(\mathrm{Du})$ by $21.97 \%$.

\footnotetext{
${ }^{1}$ Researcher, Agric. Eng. Res. Inst., Agric. Res. Center, Egypt.

${ }^{2}$ Asst. Prof. Agric. Eng. Dept., Faculty of Agric, Kafrelsheikh University, Egypt
} 
- The highest soybean yield value was $1650 \mathrm{~kg} / \mathrm{fed}$.that obtained at 100\% ETc, D1 and LP3 treatment, while the lowest soybean yield value was $683 \mathrm{~kg} / \mathrm{fed}$. that obtained at 60\% ETc, D3 and LP2 treatment. Soybean yield value was $1295 \mathrm{~kg} / \mathrm{fed}$.for traditional furrow irrigation (control treatment).

- Highest value of soil dehydrogenase was $20.4 \mathrm{mg} \mathrm{g}^{-1} \mathrm{dry}$ soil/96 $\mathrm{h}$ obtained at 100\% ETc, D1 and LP2 treatment, while the lowest value was $6.28 \mathrm{mg} \mathrm{g}^{-1}$ dry soil/96 $h$ that obtained at $60 \%$ ETc, D3 and LP1 treatment.

- The highest value of irrigation water use efficiency (IWUE)was 0.53 $\mathrm{kg} / \mathrm{m}^{3}$ obtained at $60 \%$ ETc, D1 and LP3 while the lowest value was 0.31 $\mathrm{kg} / \mathrm{m}^{3}$ obtained at $60 \% \mathrm{ETc}, \mathrm{D} 3$ and LP2.

\section{INTRODUCTION}

The worlds' population continuous to rise while water is a limited resource, thus, it is becoming increasingly difficult to continue with current irrigation practices in arid and semi-arid region of the world. Therefore, the sustainable use of water in irrigated agricultural systems with an emphasis on reducing water use requires careful planning and management. In spite of the low efficiency of surface irrigation, it is still the oldest and most used method of irrigation especially for clay soil in Egypt comparingwith sprinkler irrigation which is considered an advanced irrigation technique forwater-saving and fertigation and in accurately controlling irrigation time and water amount. Soybean is considered one of the most important industrial nutrient products. It is considered as a good source of high quality plant protein and vegetable oil.Soybean is grown in almost all parts of the world for human consumption, industry and animal feed.

Abou El-Azem et al. (2002) studied the effect of four irrigation water levels to reach the available soil moisture of $(100 \%, 85 \%, 80 \%$ and $75 \%$ from ETc) under sprinkler irrigation system, on wheat yield. They found that, the lowest yield reduction was caused by irrigation with limit of $85 \%$ from available soil moisture. Therefore, scheduling irrigation as practiced is based on the highest field water use efficiency but not the highest grain yield. Li and Rao, (2003) showed that sprinkler irrigation system 
application in clay soil increased irrigation efficiency and crop yield in addition to cooling soil and crop, especially, in summer. Amer (2006)recommended that for impact sprinklersthe spacing should be 50\% from diameter of throw in square layout and in range from 50-60\% from diameter in triangular.Kara et al (2008) determined the application limits and the curves of water distribution under different working pressures, spatial arrangement and nozzle diameters under field conditions. They found that increasing sprinkler and lateral spacing decreased Christiansen Uniformity Coefficients at the same working pressure.Saied et al. (2008) investigated the effect of sprinkler irrigation systems (semi portable sprinkler, gun, mini sprinkler and floppy sprinkler) and trickle irrigation systems (surface and subsurface) on soybean and flax production in old lands at Sakha Agricultural Station Farm, Kafr El-Sheikh Governorate, Egypt. Their results indicated that, the irrigation by mini sprinkler and subsurface drip irrigation systems achieved the highest values of water application efficiency, while the lowest values were found to be with semi portable and gun for both crops. Mini sprinkler recorded the highest value of distribution uniformity while the gun and floppy methods recorded the lowest values. They showed that irrigation by surface drip resulted in increasing the seed yield of soybean. El-Sayedet al. (2009) evaluated the performance of two types of floppy sprinklers, original type and local type under different levels of operating pressure and riser height. They showed that achieved high coefficient of uniformity, distribution uniformity and application efficiency of low quarter were operating pressure of $200 \mathrm{kPa}$ and riser height of $2 \mathrm{~m}$ for both type of floppy sprinklers. By using simulation model they reported that the spacing between sprinklers should be higher than or equal $50 \%$ of wetted diameter to avoid water lose and minimize irrigation system cost.

Amer et al. (2010) studied three sprinkler irrigation layouts (square, rectangular, and triangular), three overlapping percentages (100\%, 80\% and 60\%) and three irrigation levels (60,80 and 100\% from ETc) and its effect on peanut in sandy soil. Their results indicated that, maximum uniformity coefficient and peanut yield were obtained at $100 \%$ overlapping and 100\% from ETc under triangular layout. Hashad (2012) studied the effect of sprinkler irrigation system under Delta soil condition 
of Barley production. The results showed thatthe highest values of Christiansen's uniformity coefficient, distribution uniformity and application efficiency of low quarter were achieved by square layout. Mehawed et al. (2013) developed out the hydraulic performance analysis of different sprinkler irrigation atomization theories and corresponding nozzle sizes under arid ecosystems of Egypt. They reported that the overlapping percentage have to be not less than 50-55\% from diameter of throw for large nozzle impact sprinkler and to be $67-70 \%$ from diameter of throw for rotating sprinkler and small nozzle impact ones. Grassini et al.(2015)found that the boundary function for the relationship between soybean yield and seasonal water supply had a slope ( $\approx$ attainable water productivity) of $9.9 \mathrm{~kg} \mathrm{ha}^{-1} \mathrm{~mm}^{-1}$ and $\mathrm{x}$-intercept ( $\approx$ soil evaporation) of 73 $\mathrm{mm}$. A seasonal water supply of $650 \mathrm{~mm}$ appeared sufficient to maximize seed yield.

Before sowing seeds it is necessary to prepare a suitable seedbed for seed germination. Optimum tillage ensures the adequate moisture and air quantity needed for plant, in addition the seedbed should be as free as possible from weeds and applied fertilizer be incorporated eventually within the soil. Helmy et al. (2001) reported that using different tillage systems (Moldboard, chisel and rotary plow) in clay soil had a significant effect on corn yield. Boydak et al. (2002)said that the optimum tillage operation encourages root development and provides an optimum air water balance in the soil. Abdel-Aal et al. (2005) studied five seedbed preparation systems as (A): Chiseling one pass + leveling, (B): Chiseling twice + leveling, (C): Chiseling twice + harrowing + leveling, (D): Chiseling twice + subsoilling + harrowing + leveling and (E): Moldboarding + harrowing + leveling and four irrigation depths $(60,80$, 100 and $120 \mathrm{~mm} /$ irrigation) for rice crop. The results showed that the highest grain yield was $4.35 \mathrm{Mg} /$ fed. with $120 \mathrm{~mm}$ irrigation depth under seedbed preparation systems $\mathrm{D}$, while the lowest values were 2.67 $\mathrm{Mg} / \mathrm{fed}$.with $60 \mathrm{~mm}$ irrigation depth under seedbed preparation system(B). Soil bulk density and soil penetration resistance decreased for all seedbed preparation systems while total porosity and void ratio increased.

Watts et al. (2010)said thatDehydrogenase activity (DHA) is one of the most adequate, important and one of the most sensitive bioindicators, 
relating to soil fertility, its activity depends from the same factors which influence on microorganisms abundance and activity. Karaca et al.(2011) mentioned that many researchers had been reported different farming systems may change soil parameters especially soil microorganisms and enzymes. Dehydrogenase is an enzyme that occurs in all viable microbial cells. These enzymes function as a measurement of the metabolic state of soil microorganisms. Silva et al. (2012)reported that soil microorganisms produce a large array of enzymes which play essential roles in various ecosystem processes and are involved in the cellular metabolism, such as the decomposition of organic materials soil enzyme activity has long been considered an indicator of soil quality because it controls both the supply of nutrients to plants and microbial growth. Burns et al.(2013) mentioned that soil enzyme activities basically include the activities of dehydrogenase, urease and phosphatase enzymes. Dehydrogenase is considered to play an essential role in the oxidation of soil organic matter.

Recent research has focused on saving significant amounts of irrigation water, saving water use and developing high performance irrigation programs for growing high quality crops that utilize less water. From this point of view the main objective of this study is going to save water and increase the yield and water use efficiency of soybean crop under Egyptian clay soil conditions throw using different levels of sprinkler irrigation system and land preparation, while the specific objectives were:(1) investigate the effect of sprinkler irrigation and different land preparation systems on soybean yield in clay soil and (2) determine the optimum spatial arrangement for sprinklers and crop evapotranspiration.

\section{MATERIAL AND METHODS}

\subsection{Experimental layout:}

The field experimentswere carried out at the research farm of Rice Mechanization Center (RMC), Meet El-Deyba, Kafr El-Sheikh Governorate, Egyptwhich is located at $31^{\circ} 6^{\prime} \mathrm{N}$ latitude, $30^{\circ} 50^{\prime} \mathrm{E}$ longitude, and an elevation of about 6 meters above mean sea level during two summer seasons of 2015 and 2016. The experimental field was prepared according to suggested land preparation treatments under study and furrowed at distances of $65 \mathrm{~cm}$, soybean variety Giza 111 was planted manually in 
June 1, 2015 and May 25, 2016. It harvested in October 3, 2015 and October 1, 2016. All agronomic practices were done according to agricultural recommendations forsoybean.Table 1 showed the soil mechanical analysis, field capacity and permanentwilting pointof the experimental field were done in Soils, Water and Environmental Res. Institute Lab., Kafr El-Sheikh, Egypt.

Table 1: Soil mechanical analysis and some physical properties of experimental field.

\begin{tabular}{|c|c|c|c|c|c|c|c|}
\hline $\begin{array}{c}\text { Soil } \\
\text { depth, } \\
\text { cm }\end{array}$ & Sand,\% & $\begin{array}{c}\text { Silt, } \\
\text { \% }\end{array}$ & Clay, \% & $\begin{array}{c}\text { Soil } \\
\text { texture }\end{array}$ & $\begin{array}{c}\text { Field } \\
\text { capacity, } \%\end{array}$ & $\begin{array}{c}\text { Permanent } \\
\text { wilting } \\
\text { point, } \%\end{array}$ & $\begin{array}{c}\text { Saturation } \\
\text { hydraulic } \\
\text { conductivity, } \\
\mathrm{mm} / \mathrm{h}\end{array}$ \\
\hline $0-15$ & 10.42 & 31.25 & 58.33 & Clay & 44.80 & 21.36 & \multirow{2}{*}{25.9} \\
\cline { 2 - 7 } $15-30$ & 13.00 & 32.00 & 55.00 & Clay & 41.45 & 21.40 & \\
\hline $30-45$ & 12.00 & 29.00 & 59.00 & Clay & 39.00 & 21.00 & \\
\hline $45-60$ & 12.00 & 28.00 & 60.00 & Clay & 37.40 & 20.85 & \\
\hline
\end{tabular}

\subsection{Sprinkler irrigation network:}

Sprinkler irrigationsystem under study consisted of centrifugal pump (3 inch inlet and outlet diameters, and $30 \mathrm{~m}^{3} / \mathrm{h}$ discharges) driven by $3.75 \mathrm{~kW}$ internal combustion engine, back flow prevention device, pressure gauges, flow-meter control valves, Mainline, lateral lines and sprinklers. Main line was high density polyethylene (HDPE) pipes with $75 \mathrm{~mm}$ outer diameter, lateral lines were polyvinyl chloride(PVC) pipes with $32 \mathrm{~mm}$ outer diameter which connected to the main line by $32 \mathrm{~mm}$ control valves. Plastic impact angle sprinkler $1 / 2$ inch diameter $750 \mathrm{l} / \mathrm{h}$ discharge, $18 \mathrm{~m}$ diameter of throwat 1.25 bar pressure head and $27^{\circ}$ trajectory angle.The laterals and sprinklers were fixed in square layout.

\subsection{Treatments:}

The experimental field layout was arranged in split - split plot design as fallowed:

a-Main treatment:Three different land preparation systems (LP), LP1:Chiseling twice + leveling (traditional system),LP2: Chiseling one pass + rotary two passes + leveling andLP3: Moldboard one pass + rotary one pass + leveling. 
b-Sub main treatment: Three different distances between sprinklers and laterals (D) under square layout (overlapping ), D1: 9m (50\% diameter of throw),D2: $10.8 \mathrm{~m}$ (60\% diameter of throw) andD3: 14.5m (80\% diameter of throw).

c-Sub-sub main treatment: Three different levels of applied water from crop evapotranspiration (ETc) :60\% ETc,80\% ETc and 100\%ETc.The furrow irrigation method was used as a control treatment $(F)$ under traditional land preparation system (LP1).Experimental field layout and study treatments distribution are shown in Fig.1.



Fig. 1. The Field experiment.

\subsection{Irrigation requirement:}

The maximum and minimum temperature, relative humidity and wind speed for previous two seasons were obtained from climate station at Rice Research \&Training Center, Sakha, Kafr El-Sheikh to calculate potential 
evapotranspiration for soybean crop and average of soybean water requirements for growing seasons. CROPWAT computer program that was depending on Penman-Monteith equation was used as shown in Figs. 2 and 3. Furrow irrigation method was used two times (planting and next irrigation) then sprinkler irrigation system was applied. The following formula was used to calculate precipitation (application) rate $(\mathrm{mm} / \mathrm{hr}$ ) for sprinklers using the square inner area of the sprinklers, (Phocaides 2002).

$$
\text { P.R. }=\frac{\text { [sprinklerdischarge }] \mathrm{m}^{3} / \mathrm{hr} \times 1000}{\text { S. L }}
$$

Where:

P.R=precipitation (application) rate $(\mathrm{mm} / \mathrm{hr})$,

$\mathrm{S}=$ spacing between sprinklers, $\mathrm{m}$ and

$\mathrm{L}=$ spacing between laterals, $\mathrm{m}$.

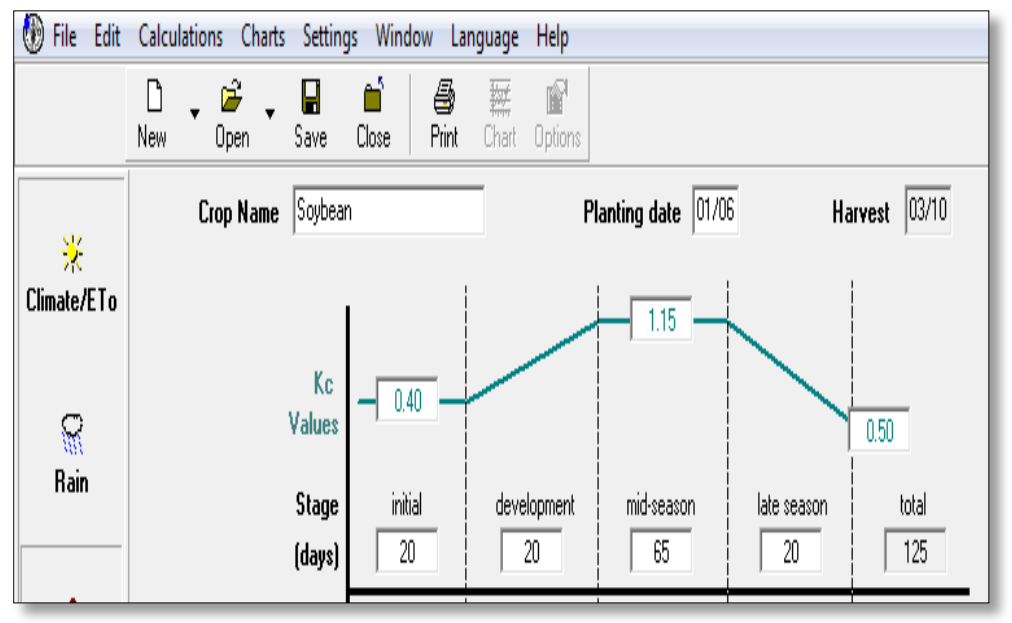

Fig. 2. Soybean crop coefficient $(\mathrm{kc})$ values at a growing stages.

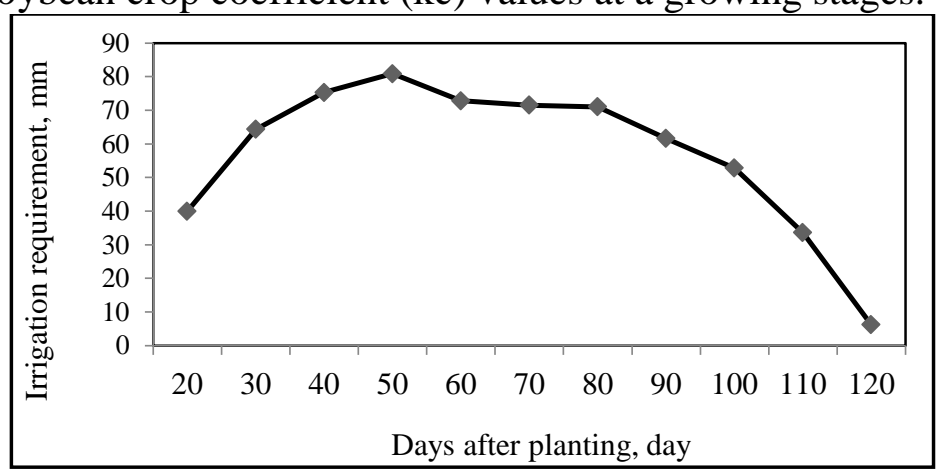

Fig. 3. An average of soybean water requirement $(\mathrm{mm})$ calculations during two growing seasons. 
The mean values of total applied water for sprinkler irrigation system under different crop evapotranspiration ratios comparing with furrow irrigation system under study were recorded during two growing seasons asshown in Table 2.

Table 2: The mean values of total applied water for sprinkler and furrow irrigation systems.

\begin{tabular}{|c|c|c|}
\hline \multicolumn{2}{|c|}{ Irrigation system } & $\begin{array}{c}\text { Totalapplied water, } \\
\left(\mathrm{m}^{3} / \mathrm{fed}\right)\end{array}$ \\
\hline \multirow{3}{*}{$\begin{array}{c}\text { Sprinkler } \\
\text { irrigation }\end{array}$} & $100 \% \mathrm{ETc}$ & 3230 \\
\cline { 2 - 3 } & $80 \% \mathrm{ETc}$ & 2700 \\
\cline { 2 - 3 } & $60 \% \mathrm{ETc}$ & 2171 \\
\hline \multicolumn{2}{|c|}{ Furrow irrigation } & 3597 \\
\hline
\end{tabular}

\subsection{Measurements}

\subsubsection{Some soil physical properties:-}

Some soil physical properties such as soil bulk density $\left(\mathrm{g} / \mathrm{cm}^{3}\right)$, soil penetration resistance $\left(\mathrm{kg} / \mathrm{cm}^{2}\right)$ and infiltrationrate $(\mathrm{mm} / \mathrm{min}$.)were measured and determined,after planting irrigation, according to standard methods.

\subsubsection{Water application uniformity:-}

Water application uniformityforsprinkler irrigation underthree differentdistances between sprinklers (D) was evaluated according to ASAE Standard (2001). James (1988) described the water application uniformity using two indicatorsas fallow:

\section{a.Christiansen uniformity $\operatorname{coefficient}\left(\mathrm{C}_{\mathrm{u}}\right)$ :}

$$
\mathrm{C}_{\mathrm{u}}=100\left(1.0-\frac{\sum\left|x_{i-} \bar{x}\right|}{n \bar{x}}\right)-------(2)
$$

Where, $\boldsymbol{x}_{\boldsymbol{i}}$ is volume caught at observation point $\boldsymbol{i}, \bar{x}$ is average volume amount caught and $\boldsymbol{n}$ number of observations.

\section{b. Water distribution uniformity (Du) :}

$$
\mathrm{Du}=100 \times \frac{x_{\mathrm{lq}}}{\bar{x}}-------------(3)
$$

Where, $\boldsymbol{x}_{\mathbf{l q}}$ is low-quarter average volume amount caughtat observation points. 


\subsubsection{Soybean yield and its component:-}

Total soybean yield (kg/fed.) and its component such as ( height of main stem $(\mathrm{cm})$, average number of fruiting branches/plant, average number of pods/ plant, height of first pod $(\mathrm{cm})$ and weight of 100 seeds $(\mathrm{g})$ were determined and calculated for all treatments under study.

\subsubsection{Determination of soil dehydrogenase activity}

Three replicates of soil samples from land preparation systems under different levels of crop evapotranspiration were taken to determine the Dehydrogenase activity in the microbiology laboratory, Soil Science and Water Institute according to analyzing method described by Tabatabai (1982). Dehydrogenases convert 2,3,5-triphenyl tetrazolium chloride to formazan. The absorbance of formazan was read spectrophotometrically at $485 \mathrm{~nm} .1 \mathrm{~g}$ of sieved soil was placed in test tubes $(15 \mathrm{x} 100 \mathrm{~mm})$, mixed with $1 \mathrm{ml}$ of 3\% aqueous (w/v) 2,3,5-triphenyl tetrazolium chloride and stirred with a glass rod. After $96 \mathrm{~h}$ of incubation $\left(27^{\circ} \mathrm{C}\right) 10 \mathrm{ml}$ of ethanol was added to each test tube and the suspension was vortexed for $30 \mathrm{~s}$. The tubes were then incubated for $1 \mathrm{~h}$ to allow suspended soil to settle. The resulting supernatant $(5 \mathrm{ml})$ was carefully transferred to clean test tubes using Pasteur pipettes. Absorbance was read spectrophotometrically at $485 \mathrm{~nm}$

\subsubsection{Irrigation water use efficiency:-}

Irrigation water use efficiency, IWUE, $\left(\mathrm{kg} / \mathrm{m}^{3}\right)$ was calculated as following:

$$
\text { IWUE }=\frac{\text { Total yield, }(\mathrm{kg} / \mathrm{fed})}{\text { Total applied irrigation water, }\left(\mathrm{m}^{3} / \mathrm{fed}\right)}-------
$$

Statistical analysis was carried out by CoStat program for windows.

\subsection{Some soil physical properties:-}

\section{RESULTS AND DISCUSSION}

\section{a. Soil bulk density:}

The effect of different land preparation systems on soil bulk density is shown in Fig.4. The soil bulk density increased with increasing the soil depth in all treatments where soil compaction increased. The results indicated that land preparation system, LP3, (Moldboard one pass + rotary one pass + leveling) gave the least soil bulk density for three layers comparing with other land preparation systems, where it was 1.06, 1.20 
and $1.27 \mathrm{~g} / \mathrm{cm}^{3}$ for three layers $0-10,10-20$ and $20-30$, respectively. Highest bulk density for first layer $1.16 \mathrm{~g} / \mathrm{cm}^{3}$ obtained attraditional land preparation system LP1 (Chiseling twice + leveling), while the highest bulk density for second and third layers 1.24 and $1.32 \mathrm{~g} / \mathrm{cm}^{3}$ obtained by land preparation system LP2 (Chiseling one pass + rotary two passes + leveling). Using moldboard plow decrease soil bulk density and enhance soil properties where breakdown of soil structure was happened.

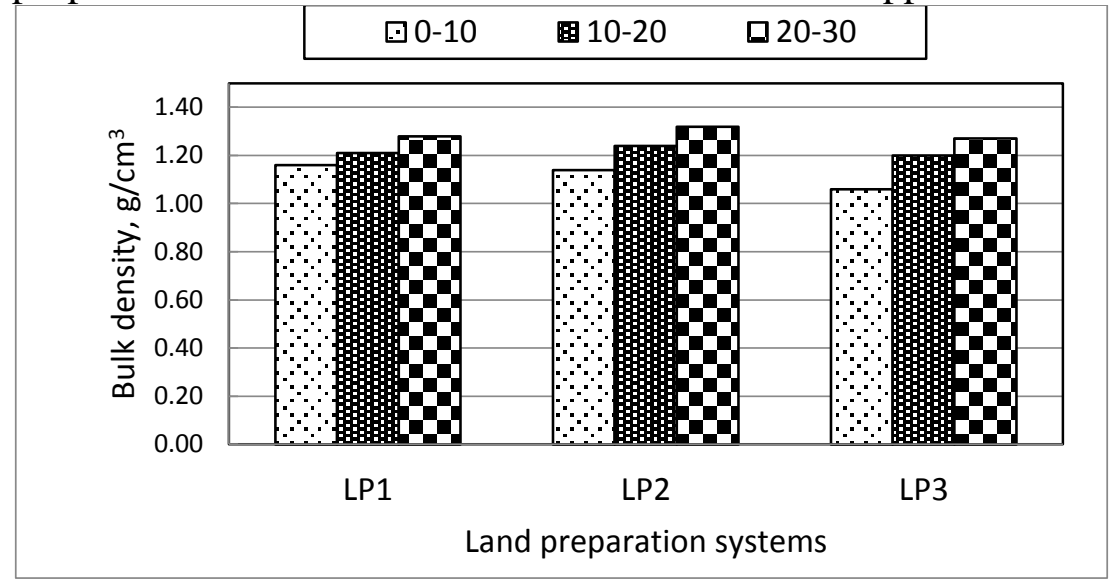

Fig.4. The mean values of soil bulk density $\left(\mathrm{g} / \mathrm{cm}^{3}\right)$ for different land preparation systems.

\section{b. Soil penetration resistance:}

Soil penetration resistance is a good indicator for soil physical properties where decreasing penetration resistance means plants roots can penetrate the soil easily. Fig.5 showed effect of land preparation systems on soil penetration resistance $\left(\mathrm{kg} / \mathrm{cm}^{2}\right)$ at three soil depths 10,20 and $30 \mathrm{~cm}$. The results revealed that soil penetration resistance increased by increasing soil depth for all land preparation systems where soil compaction increased. The results showed that the effect of different land preparation systems on soil penetration resistance decreased by increasing soil depth. Land preparation system LP3 (Moldboard one pass + rotary one pass + leveling) gave the least soil penetration resistance for three depths comparing with other land preparation systems, where it was 6, 11.5 and $18 \mathrm{~kg} / \mathrm{cm}^{2}$ for three depths 10,20 and $30 \mathrm{~cm}$ respectively. Highest bulk density for first depth $8.75 \mathrm{~kg} / \mathrm{cm}^{2}$ obtained by traditional land preparation system LP1 (Chiseling twice + leveling), while the highest bulk density 
for second and third depths 13 and $18.8 \mathrm{~kg} / \mathrm{cm}^{2}$ obtained by land preparation system LP2 (Chiseling one pass + rotary two passes + leveling). LP3 decreased soil bulk density for three depths 10, 20 and 30 cm comparing with LP2 and LP1 by $17.24,11.53,4.25 \%$ and by 31.42 , $2.54,1.6 \%$ respectively.

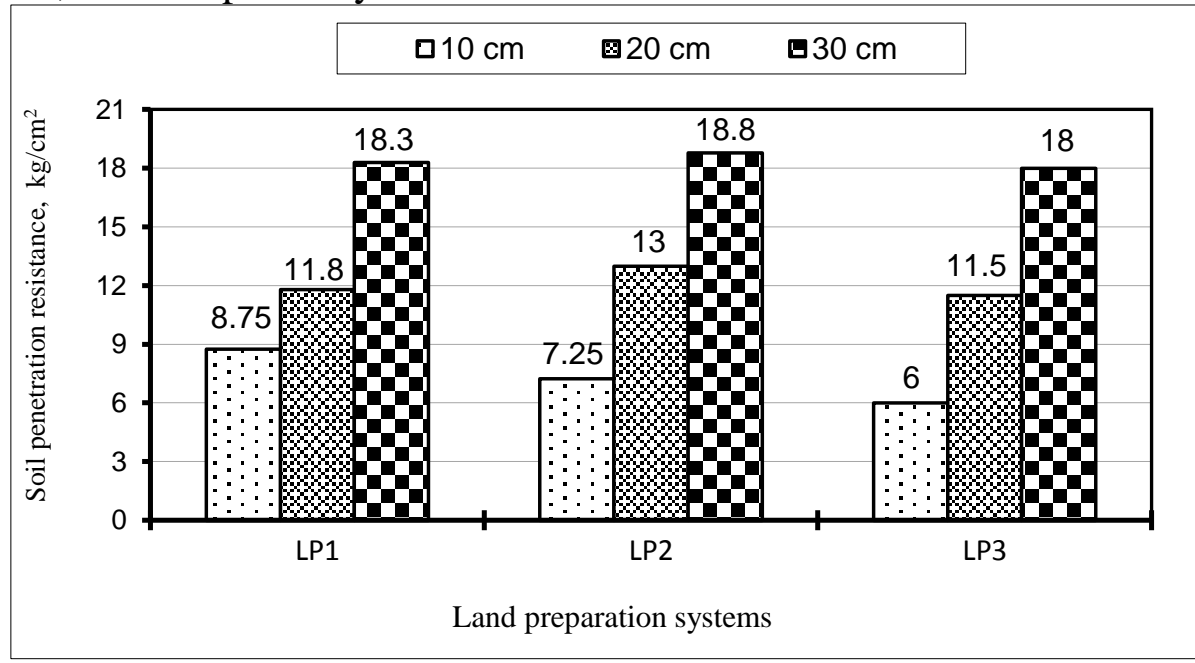

Fig. 5. The mean values of soil penetration resistance $\left(\mathrm{kg} / \mathrm{cm}^{2}\right)$ for different land preparation systems.

\section{c. Infiltration rate:-}

Fig.6 shows relationship between time (min.) on infiltration rate $(\mathrm{mm} / \mathrm{h})$ at different land preparation systems. The results showed that infiltration rate decreased by increasing of time infiltration. It decreased rabidly in the first stage and then tends to steady after 90 min of infiltration time at all land preparation treatments. The highest infiltration rates were observed in the LP1 treatment and were greater than the infiltration rates observed in LP2 and LP3 treatments. The treatment of LP3 achieved the lowest mean values of infiltration rate due to decrease soil bulk density. Average of infiltration rates were 13.2, 5.4 and $2 \mathrm{~mm} / \mathrm{h}$ using LP1, LP2 and LP3 land preparation systems, respectively achieved and steadied after infiltration time about of $110 \mathrm{~min}$. These results are very important to know the applied water depth when operating of sprinkler irrigation system treatments. 


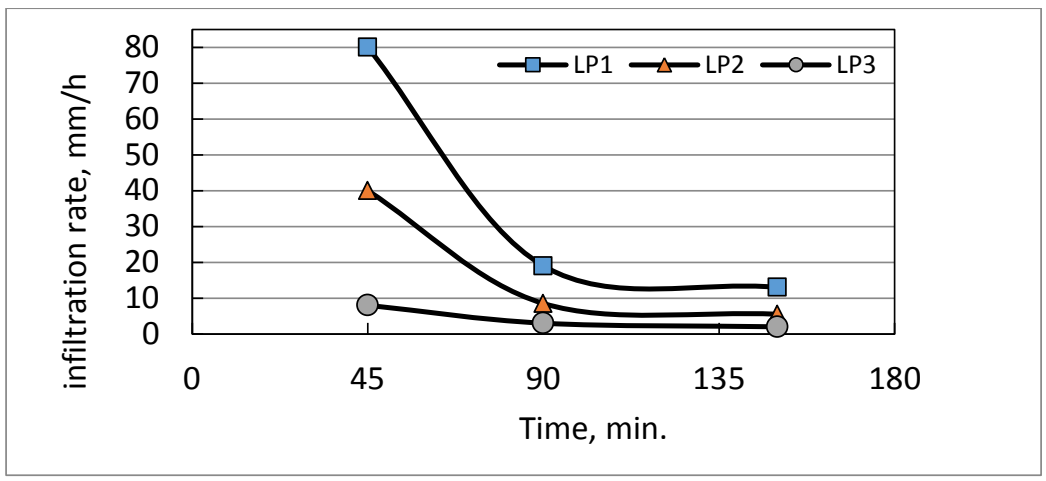

Fig. 6.The mean values of infiltration rate $(\mathrm{mm} / \mathrm{h})$ as affected by different land preparation systems.

\subsection{Water application uniformity:-}

The effect of different distances between sprinklers (D) on Christiansen uniformity coefficient $\left(\mathrm{C}_{\mathrm{u}}\right)$ and distribution uniformity $(\mathrm{Du})$ showed in Fig.7 .The results indicated thatChristiansen uniformity coefficient $\left(C_{u}\right)$ and distribution uniformity $(\mathrm{Du})$ were affected by distance between sprinklers. Increasing distance between sprinklers from $9 \mathrm{~m} \quad(50 \%$ diameter of throw) to $14.5 \mathrm{~m}$ ( $80 \%$ diameter of throw) decreased $\left(\mathrm{C}_{\mathrm{u}}\right)$ and $(\mathrm{Du})$, this is may be due to increasing the layout area concerned for every sprinkler. Maximum values for $\left(\mathrm{C}_{\mathrm{u}}\right)$ and $(\mathrm{Du})$ were $80.8 \%$ and $76.9 \%$ respectively at $9 \mathrm{~m}$ distance between sprinklers, where minimum values were $71.8 \%$ and $60 \%$ respectively at $14.5 \mathrm{~m}$ distance between sprinklers, these results were agreement with Amer (2006). It could be recommended that the optimum distance between sprinklers for small impact sprinklers under square layout were $9 \mathrm{~m}$ (50\% diameter of throw).

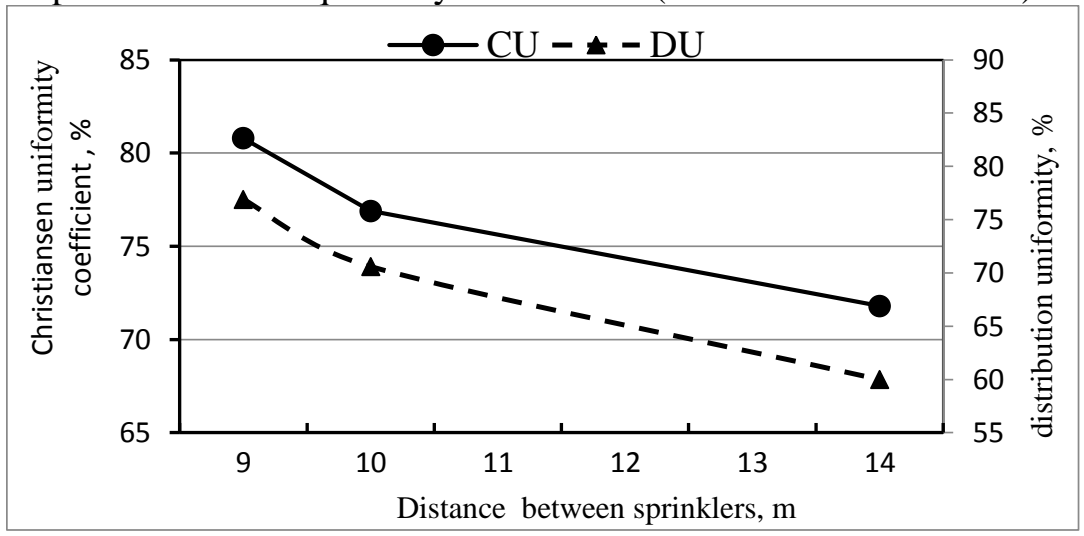

Fig 7.Effect of distance between sprinklerson Christiansen uniformity coefficient and distribution uniformity. 


\subsection{Soybean yield and its components:- \\ a. Soybean yield:-}

The obtained results of soybean yield indicated that, there is a positive correlation between land preparation systems and soybean yield. Using land preparation system of LP3 gave the highest yield at any given of distance between sprinklers (D) and water levels of crop evapotranspiration (ETc) under study, while the land preparation system of LP2 gave the lowest value of yield at any given of distance between sprinklers (D) and evapotranspiration levels (ETc) under study as shown in Fig. 8. These results may be due to that, LP3 made more granular soil, which helped in the spread of the roots more easily. In regarding to the effect ofevapotranspiration levels (ETc) and distance between sprinklers (D) on soybean yield, it could be cleared thatincreasing water level of crop evapotranspiration (ETc) and decreasing the distance between sprinklersincreased soybean yield.These results may be due to increasing total water applied to unit area which gave a good vegetative and fruit growth. The soybean yield was increased by $13.14 \%$ due to decreasing thedistance between sprinklers from D2 $(10.8 \mathrm{~m})$ to D1 $(9 \mathrm{~m})$ under land preparation system LP1at $60 \%$ ETccomparing with $9.83 \%$ and $10.29 \%$ using land preparation systems of LP2 and LP3 respectively.Also, the increment percentage about $13.54,14.29$ and $21.07 \%$ were obtained due to increasing evapotranspiration levels (ETc) from 60 to $80 \%$ when using $9 \mathrm{~m}$ distance between sprinklers (D1)under land preparation systems LP1, LP2 and LP3 respectively.From the results it could be concluded that the highest soybean yield was $1650 \mathrm{~kg} / \mathrm{fed}$. obtained at $100 \%$ evapotranspiration (100\% ETc), 9m distance between sprinklers $(50 \%$ diameter of throw) and land preparation system (LP3) (Moldboard one pass + rotary one pass + leveling,), where it increased by $27.41 \%$ comparing with control treatment $(\mathrm{F})$, on the other hand The lowest soybean yield was $683 \mathrm{~kg} / \mathrm{fed}$. obtained at $60 \%$ evapotranspiration $(60 \%$ ETc), $14.5 \mathrm{~m}$ distance between sprinklers (80\% diameter of throw) and land preparation system (LP2) (Chiseling one pass + rotary two passes + leveling), it decreased by $47.26 \%$ comparing with control treatment (F), where furrow irrigation gave $1295 \mathrm{~kg}$ soybean yield. The effect of land preparation systems (LP) distance between sprinklers (D) and crop 
evapotranspiration ETc and interaction between them were high significant at $1 \%$ level on soybean yield. Fig. 6 showed the Effect of different parameters on soybean yield ( $\mathrm{kg} / \mathrm{fed}$.).

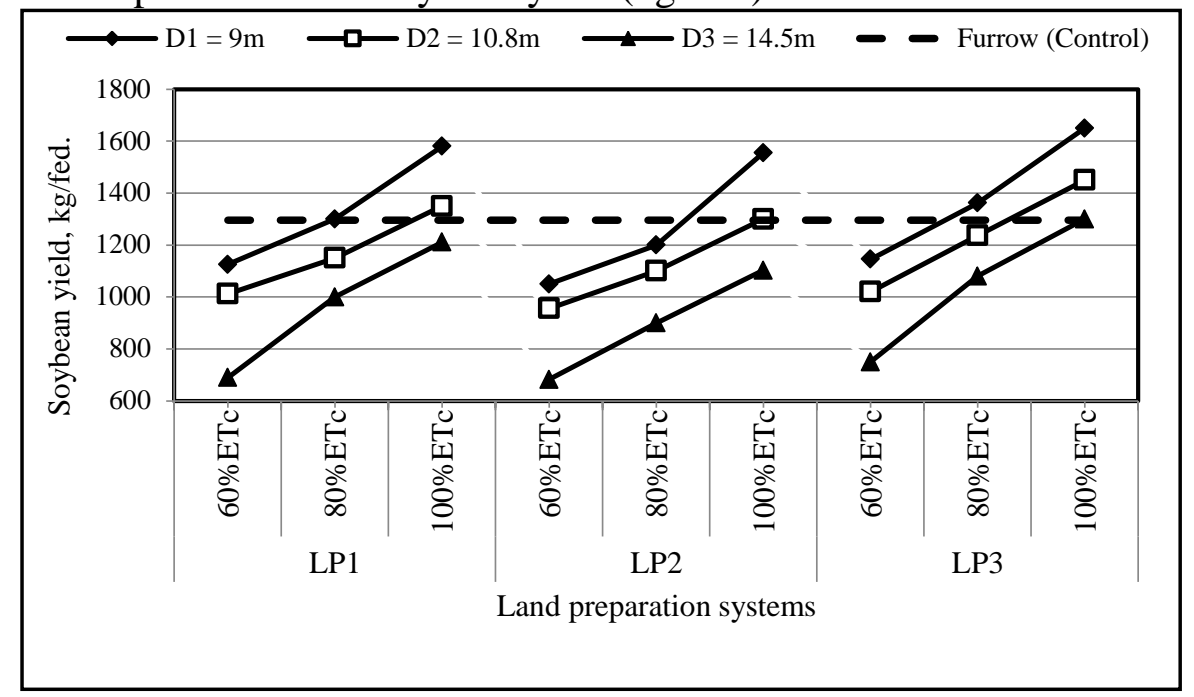

Fig. 8. Effect of land preparation systems (LP), distance between sprinklers (D) and water levels of crop evapotranspiration (ETc) on soybean yield.

\section{b. Soybean yield components:-}

The effect of land preparation systems (LP),distance between sprinklers(D) and water levels of crop evapotranspiration (ETc) on weight of 100 seeds $(\mathrm{g})$, number of pods/plant, height of first pod $(\mathrm{cm})$, Plant height $(\mathrm{cm})$ and number of fruit branches listed in Table 3. Maximum weight of 100 seeds (g) was $14.4 \mathrm{~g}$ at LP3, 100\%ETc and D1 and the minimum value was $10 \mathrm{~g}$. at LP3, 60\%ETcand D3 while furrow irrigation gave $10.4 \mathrm{~g}$. weight of 100 seeds. The maximum and minimum numbers of pods/plant were 175.8 and 38.7 at LP2, ETc $80 \%$ and D1 and LP1, ETc $80 \%$ and D3 while furrow irrigation gave 84.5 pods/plant but it was observed that number of seeds /pod varied from one to three seeds. Height of first pod $(\mathrm{cm})$ is an important indicator in mechanical harvest where determine height of cutting bar. Minimum height of first pod was $9.8 \mathrm{~cm}$ which obtained at LP2, 100\%ETcand D1so harvesting height must not increases than $9.8 \mathrm{~cm}$ to avoid losses in pods. Plant height is an indicator for soybean yield where increasing plant height means increasing number 
of fruit branches. Under sprinkler irrigation system plant height is consider an indicator for determine raiser height. Maximum and minimum plant height was $120 \mathrm{~cm}$ and $80 \mathrm{~cm}$ at LP1, ETc $100 \%$ and D2 and LP3, 60\%ETc and D2 respectively. Plant height under furrow irrigation was $111 \mathrm{~cm}$. so height of sprinkler raiser must be more than 120 $\mathrm{cm}$.

Table 3: Effect of land preparation systems (LP), distance between sprinklers(D) and crop evapotranspiration (ETc) on Weight of 100 seeds $(\mathrm{g})$, number of pods, height of first pod $(\mathrm{cm})$, Plant height $(\mathrm{cm})$ and number of fruit branches.

\begin{tabular}{|c|c|c|c|c|c|c|c|c|c|c|}
\hline \multirow{2}{*}{ ETc } & \multirow{2}{*}{$\begin{array}{c}\text { Yield } \\
\text { components }\end{array}$} & \multicolumn{3}{|c|}{ LP1 } & \multicolumn{3}{|c|}{ LP2 } & \multicolumn{3}{|c|}{ LP3 } \\
\hline & & D1 & $\mathrm{D} 2$ & D3 & D1 & D2 & D3 & D1 & $\mathrm{D} 2$ & D3 \\
\hline \multirow{4}{*}{$\begin{array}{c}100 \% \mathrm{ET} \\
\mathrm{c}\end{array}$} & $\begin{array}{l}\text { Weight of } 100 \\
\text { seeds, } g\end{array}$ & 12.3 & 12 & 10.6 & 12 & 12 & 10.3 & 14.4 & 13.3 & 12.7 \\
\hline & $\begin{array}{l}\text { Number of } \\
\text { pods/plant }\end{array}$ & 104 & 79 & 64 & 131 & 55 & 43 & 164 & 121 & 75 \\
\hline & $\begin{array}{l}\text { Height of first } \\
\text { pod, } \mathrm{cm}\end{array}$ & 14.6 & 15.7 & 14 & 9.8 & 18.3 & 12 & 13.5 & 16.5 & 17.8 \\
\hline & Plant height, $\mathrm{cm}$ & 113 & 120 & 85 & 110 & 97 & 84.8 & 102 & 98.5 & 95 \\
\hline \multirow{4}{*}{$80 \%$ ETc } & $\begin{array}{l}\text { Weight of } 100 \\
\text { seeds, g }\end{array}$ & 11.8 & 11.2 & 10.5 & 11 & 10.3 & 10.1 & 12.6 & 11.7 & 10.3 \\
\hline & Number of pods & 115 & 70 & 53 & 176 & 62 & 66 & 99 & 86 & 73 \\
\hline & $\begin{array}{l}\text { Height of first } \\
\text { pod, cm }\end{array}$ & 16.5 & 14 & 15 & 13.7 & 15.9 & 15.9 & 19.5 & 18.6 & 15 \\
\hline & Plant height, $\mathrm{cm}$ & 106 & 101 & 84 & 85 & 103 & 87 & 101 & 102 & 86 \\
\hline \multirow{4}{*}{$60 \% \mathrm{ETc}$} & $\begin{array}{l}\text { Weight of } 100 \\
\text { seeds, g }\end{array}$ & 11.2 & 11 & 10.5 & 10 & 10.9 & 10.7 & 11.5 & 11 & 10 \\
\hline & Number of pods & 88 & 75 & 39 & 94 & 62 & 67 & 100 & 69 & 45 \\
\hline & $\begin{array}{l}\text { Height of first } \\
\text { pod, } \mathrm{cm}\end{array}$ & 17.5 & 14.7 & 24.5 & 11.9 & 15 & 15 & 16.6 & 13 & 17 \\
\hline & Plant height, $\mathrm{cm}$ & 100 & 102 & 95 & 96.7 & 89 & 98 & 102 & 80 & 108 \\
\hline \multirow{4}{*}{ Furrow } & $\begin{array}{l}\text { Weight of } 100 \\
\text { seeds, g }\end{array}$ & \multicolumn{9}{|c|}{10.4} \\
\hline & Number of pods & \multicolumn{9}{|c|}{85} \\
\hline & $\begin{array}{l}\text { Height of first } \\
\text { pod, } \mathrm{cm}\end{array}$ & \multicolumn{9}{|c|}{19} \\
\hline & Plant height, $\mathrm{cm}$ & \multicolumn{9}{|c|}{111} \\
\hline
\end{tabular}

\subsection{Effect of land preparation and irrigation systems on soil dehydrogenaseactivity}

Soil dehydrogenase activity was considered an indicator for soil quality. As illustrated the results in Fig.9 indicated that, there is a positive correlation between land preparation systems and soil dehydrogenase activity. Using land preparation system of (LP2) gave the highest soil dehydrogenase activity at any given of distance between sprinklers (D) 
and water levels of crop evapotranspiration (ETc) under study, while the land preparation system of LP1 gave the lowest value of soil dehydrogenase activity at any given of distance between sprinklers (D) and evapotranspiration levels (ETc) under study except D3 for (LP1) and (LP3) at 60\%(ETc) gave lowest value comparing to control that mean less and more total water applied have negative effect on soil dehydrogenase activity at this case.In regarding to the effect of evapotranspiration levels (ETc) and distance between sprinklers (D) on soil dehydrogenase activity, it could be cleared thatincreasing water level of crop evapotranspiration (ETc) and decreasing the distance between sprinklers increased soil dehydrogenase activity.The soil dehydrogenase activity was increased by $13.13 \%$ due to decreasing thedistance between sprinklers from D2 $(10.8 \mathrm{~m})$ to $\mathrm{D} 1 \mathrm{(9 \textrm {m } )}$ at land preparation system of LP1compared with 9.89\% and $10.26 \%$ using land preparation systems of LP2 and LP3 respectively, at $60 \%$ ETc. Also, the increment percentage about 13.53, 14.39 and $21.07 \%$ were obtained due to increasing evapotranspiration levels (ETc) from 60 to $80 \%$ when using $9 \mathrm{~m}$ distance between sprinklers (D1) at land preparation systems of LP1, LP2 and LP3, respectively.



Fig. 9. Effect of land preparation systems (LP),distance between sprinklers (D) and water levels of crop evapotranspiration (ETc)on soil dehydrogenase activity $\mathrm{mg} \mathrm{g}^{-1}$ dry soil/96 $\mathrm{h}$ 
The results could be cleared that the highest soil dehydrogenase activity was $20.4 \mathrm{mg}$ g-1dry soil/96 h obtained at (100\% ETc), D1 (9m distance between sprinklers) and land preparation system (LP2), where it increased by $156.6 \%$ comparing with control treatment $(\mathrm{F})$, on the other hand The lowest soil dehydrogenase activity was $6.28 \mathrm{mg}$ g-1dry soil/ $/ 96 \mathrm{~h}$ obtained at $(60 \%$ ETc), D3 (14.5m distance between sprinklers) and land preparation system (LP1), where it decreased by $93.7 \%$ comparing with control treatment (F), furrow irrigation gave $7.95 \mathrm{mg}$ g-1dry soil/96 hsoil dehydrogenase activity.The effect of land preparation systems (LP) distance between sprinklers (D) and crop evapotranspiration ETc and interaction between them were high significant at $1 \%$ level on soil dehydrogenase activity.

\subsection{Irrigation Water Use Efficiency, IWUE:-}

The obtained results of IWUE indicated that, there is a positive correlation between land preparation systems and IWUE. Using land preparation system of LP3 gave the highest IWUE at any given of distance between sprinklers (D) and water levels of crop evapotranspiration (ETc) under study, while the land preparation system of LP2 gave the lowest value of IWUE at any given of distance between sprinklers (D) and evapotranspiration levels (ETc) under study as shown in Fig. 10. In regarding to the effect of distance between sprinklers (D) on IWUE it could be showed that IWUE decreased by increasing the distance between sprinklers (D), where soybean yield increasedwhile total water applied is fixed under the same level of evapotranspiration. At $14.5 \mathrm{~m}$ distance between sprinklers (D1), IWUE increased by increasing levels of crop evapotranspiration (ETc) from 60 to $80 \%$ under different land preparation systems, on the other hand increasing levels of crop evapotranspiration (ETc) from 80 to $100 \%$ IWUE did not change under LP1 and LP3 because there is a balance in increasing soybean yield and total water applied. While, it increased under LP2. At $10.8 \mathrm{~m}$ distance between sprinklers (D2) irrigation water use efficiency decreased by increasing levels of crop evapotranspiration (ETc) from 60 to $100 \%$ under different land preparation systems. At $9 \mathrm{~m}$ distance between sprinklers(D1) water use efficiency decreased by increasing levels of crop evapotranspiration (ETc) from 60 to $80 \%$ under different land preparation 
systems, on the other hand increasing levels of crop evapotranspiration (ETc) from 80 to $100 \%$ IWUEincreased.The water use efficiency was increased by10.64 \%due to decreasing thedistance between sprinklers from D2 $(10.8 \mathrm{~m})$ to D1 $(9 \mathrm{~m})$ at land preparation system of LP1compared with $9.09 \%$ and $12.77 \%$ under land preparation systems of LP2 and LP3 respectively, at $60 \%$ ETc. Also, the decrement percentage about 7.69, 8.33 and $5.66 \%$ were obtained due to increasing evapotranspiration levels (ETc) from 60 to $80 \%$ when using $9 \mathrm{~m}$ distance between sprinklers (D1)under land preparation systems of LP1, LP2 and LP3, respectively. The highest IWUE was $0.53 \mathrm{~kg} / \mathrm{m}^{3}$ obtained at $(60 \%$ ETc), D1 $(9 \mathrm{~m}$ distance between sprinklers) and land preparation system (LP3), where it increased by $47.22 \%$ comparing with control treatment $(\mathrm{F})$, whilethe lowest value was $0.31 \mathrm{~kg} / \mathrm{m}^{3}$ obtained at $(60 \%$ ETc), D3 (14.5m distance between sprinklers)and land preparation system (LP2), where it decreased by $13.88 \%$ comparing with control treatment $(\mathrm{F})$, furrow irrigation gave IWUE of $0.36 \mathrm{~kg} / \mathrm{m}^{3}$. The effect of land preparation systems (LP) distance between sprinklers (D) and crop evapotranspiration ETc and interaction between them were high significant at $1 \%$ level on IWUE.

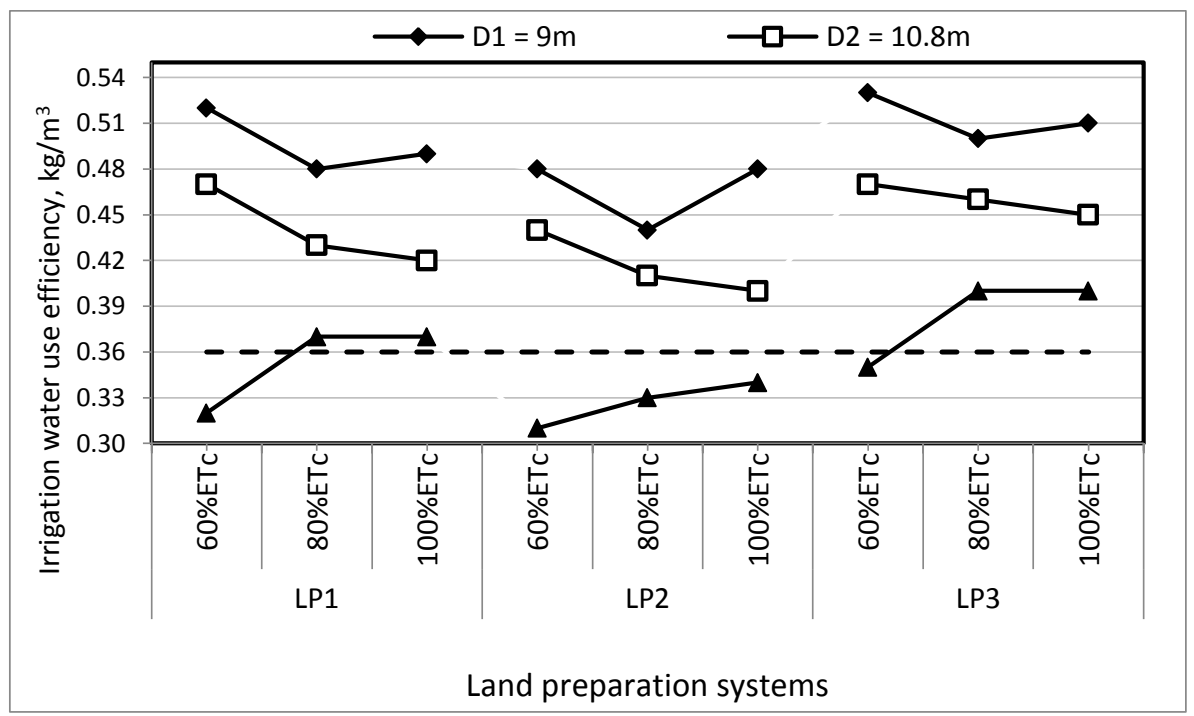

Fig. 10. Effect of land preparation systems (LP),distance between sprinklers (D) and water levels of crop evapotranspiration (ETc)on irrigation water use efficiency. 


\section{CONCLUSION}

Total applied water under sprinkler irrigation system was 2171, 2700 and $3230 \mathrm{~m}^{3} /$ fed.at three levels of crop evapotranspiration $60 \%$ ETc, $80 \%$ ETc, $100 \%$ ETc, respectively while total water applied under furrow irrigation was $3597 \mathrm{~m}^{3} / \mathrm{fed}$. Using sprinkler irrigation system in clayey soil at 50\% diameter of throw improves water application uniformity (Christiansen uniformity coefficient $\left(\mathrm{C}_{\mathrm{u}}\right)$ and distribution uniformity (Du)), adding $100 \%$ of crop evapotranspiration increase soybean yield and land preparation system (Moldboard one pass + rotary one pass + leveling ) enhances soil physical properties and soil microorganism activity so soybean yield increase.

\section{REFERENCES}

Abdel-Aal, S. E.; A. M. Kishta and A. Lotfy (2005). Seedbed preparation and irrigation depths affecting soil physical properties and rice yield. Misr J. Ag. Eng., 22 (2): 572-591.

Abou El-Azem, A.; A. Nassar; T. Hussien and A. El-Ghamry (2002). Irrigation effects on wheat yield under sprinkling in sandy soil. Misr J. Ag. Eng., 19 (1): 123-135.

Amer, K. H. (2006). Water distribution uniformity as affected by sprinkler performance. Misr J. Ag. Eng., 23 (1):82-94.

Amer, K. H.; A. H. Gomaa and E. A. Farag (2010). Peanut crop response to non-uniformity of irrigation application under sprinkler system performance. The $17^{\text {th }}$ Annual Conference of Misr J. Ag. Eng., Egypt, 28 Oct.:1193-1211.

ASAE Standard. (2001). Procedure for sprinkler testing and performance reporting .ASAE, Standard S398.1 JAN01:880-882.

Boydak, E.; M. Alpaslan; M. Hayta; S. Gercek and M. Simsek (2002).Seed composition of soybeans grownin the Harran region of Turkey as affected by row spacing and irrigation. J. Ag. Food Chem., 50: 4718-4720.

Burns, R. G. ;J. L. DeForest; J. Marxsen; R. L. Sinsabaugh; M. E. Stromberger; M. D. Wallenstein; M. N. Weintraub; and A. Zoppini (2013). Soil enzymes in a changing environment: current 
knowledge and future directions. Soil Biology and Biochemistry 58, 216-234.

El-Sayed, A. S; M. M. Hegazi; I. H. El-Sheikh and A. F. Khader (2009). Performance evaluation of floppy sprinklers. Misr J. of Agric. Eng.,26(2): 766-782.

Grassini, P.; J. A.Torrion; H. S. Yang; J. Rees; D. Andersen; K. G. Cassman and J. E. Specht (2015). Soybean yield gaps and water productivity in the western US Corn Belt. Field Crops Research, 179, 150-163.

Hashad, A. M. (2012). Utilization of sprinkler irrigation system under Delta soil conditions.Ph.D. Thesis. Agric. Mech. Dept., Fac. of Agric.TantaUniv, Egypt.

Helmy, M. A.; S.A. Gomaa; H. M. Sorour and H. A. El-Khateeb (2001). Effect of some different seedbed preparation systems on irrigation water consumption and corn yield. Misr J. Ag. Eng., 18 (1): 169-181.

James, L. G. (1988). Principles of farm irrigation system design. John willey\& Sons. New York, pp: 91.

Kara, T.; E. Ekmekci and M. Apan (2008). Determining the uniformity coefficient and water distribution characteristics of some sprinklers. Pakistan Journal of Biological Sciences, 11 (2): 214-219.

Karaca A.; S. C. Cetin; O. C. Turgay and R. Kizilkaya (2011). Soil enzymes as indication of soil quality. In: Shukla G., Varma A. (eds.): Soil Enzymology. Springer-Verlag, Berlin, Heidelberg, 119148.

Li,J. and M. Rao. (2003). Field evaluation of crop yield as affected by nonuniformity of sprinkler-applied water and fertilizers. Agricultural Water Management 59: 1-13.

Mehawed, H. S.; A. M. El-Shazly and Y. E. Arafa (2013). Hydraulic performance assessment of sprinkler types for improving on-farm irrigation efficiencies. Third international conference for agricultural \& bio-engineering. Egypt. J. Ag. Res., 91 (2A):367379. 
Phocaides, A. (2002). Technical handbook on pressurized irrigation techniques. Rome: FAO, 101.

Saied, M. M.; M. M. Ragab; S. M. El-Barbary and M. I. El-Shawy (2008). Effect of pressurized irrigation system on soybean and flax yields and some water relations in old lands. Misr J. Ag. Eng., 25 (1): 87-101.

Silva, D. K. A.; N. O. Freitas; R. G. Sousa; F. S. B. Silva; A. S. F. Araújo and L. C. Maia (2012). Soil microbial biomass and activity under natural and regenerated forests and conventional sugarcane plantations in Brazil. Geoderma 189, 257-261.

Tabatabai M.A. (1982). Soil enzymes, Dehydrogwenases. In: Methods of Soil Analysis. Part 2.Chemical and Microbiolgical Properties (Eds R.H. Miller and D.R. Keeney).Agron.Monography, 9, ASA and SSSA, Madison, WI.

Watts D. B., H. A. Torbert; Y. Feng and S. A. Prior (2010). Soil microbial community dynamics as influenced by composted dairy manure, soil properties, and landscape position. Soil Science, 175: 474-486.

\section{الملخص العربي}

تأثير الري بالرش ونظم إعداد التربة علي إنتاجية محصول فول الصويا في الأراضي الطينية

د. طارق محمود عطافي 'د. وائل فتحي المتولي'د. عبدالعزيز محمد عكاثة'

تم إجراء تجربة حقلية بالمزرعة البحثية بمركز ميكنة الأرز بميت الديبة بمحافظة كفر الثيخ

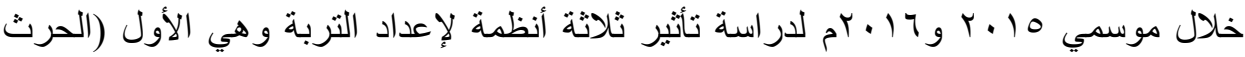



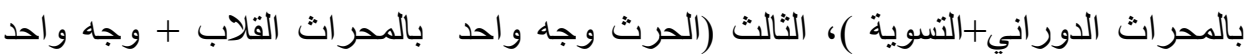

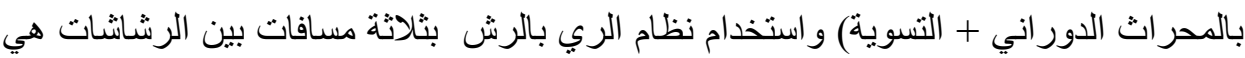

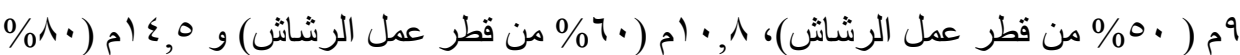

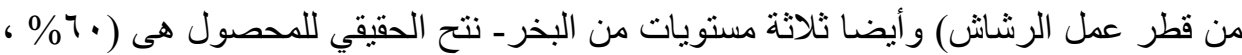

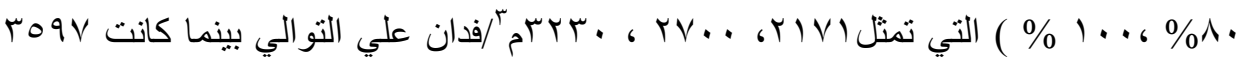

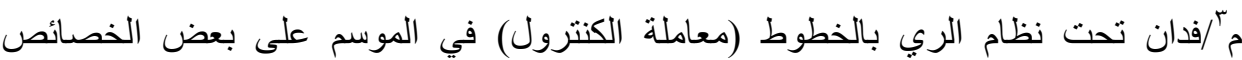

'باحث ـ معهد بحوث الهندسة الزراعية ـمركز البحوث الزراعية ـمصر.

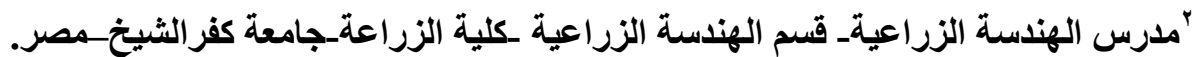


الفيزيائية للتربة ،كفاءة توزيع المياه، إنتاجية محصول فول الصويا، خصائص المحصول، كفاءة استخدام مياه الري وذللك في التربة الطينية. وكانت أهم النتائج المتحصل عليها:-

حقق نظام إعداد التربة الثالث انخفاض منوسط قيمة الكثافة الظاهرية للتربة بالمقارنة بنظام

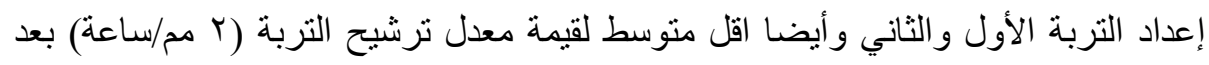

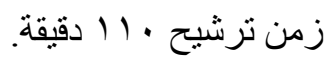

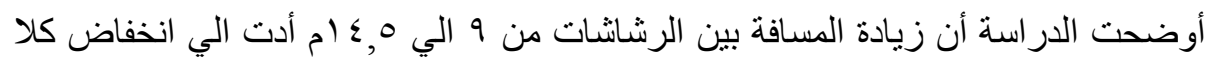

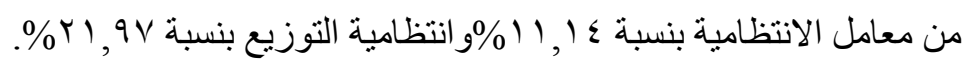

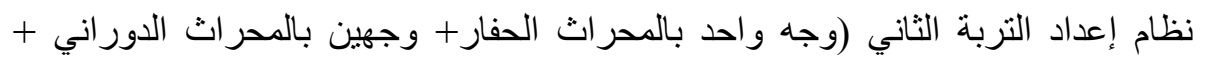

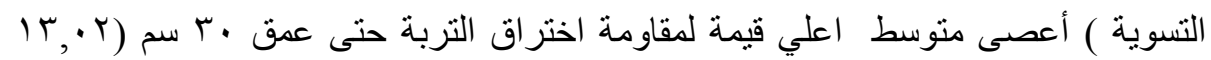



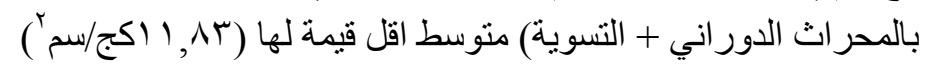



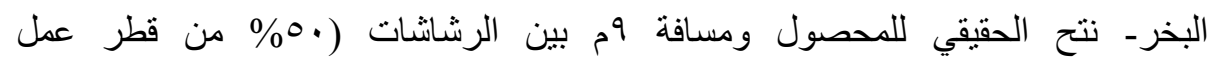

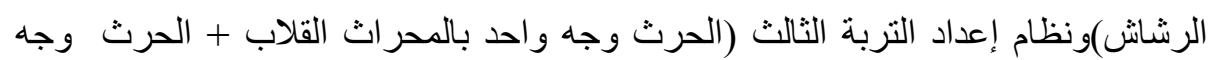

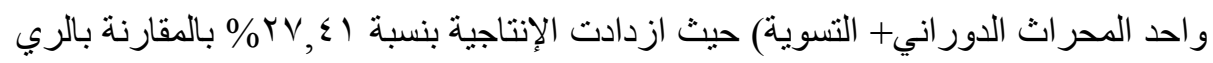

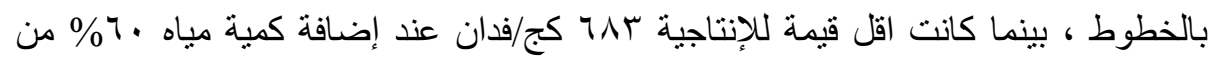

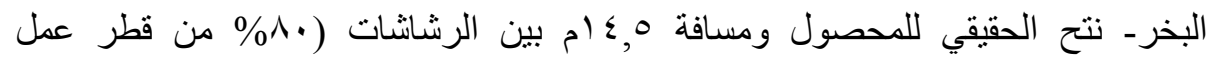

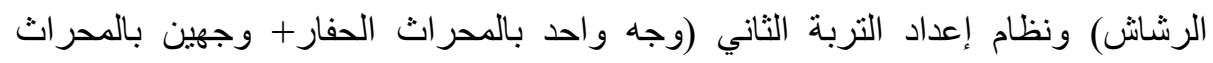

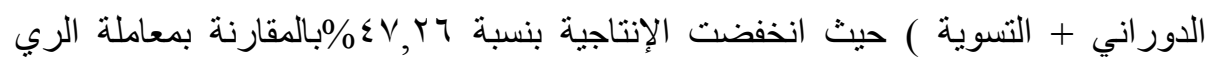
بالخطوط.

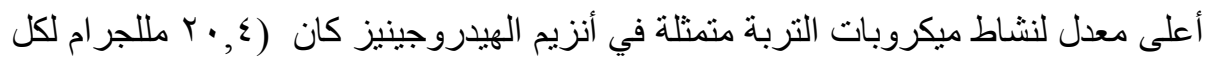

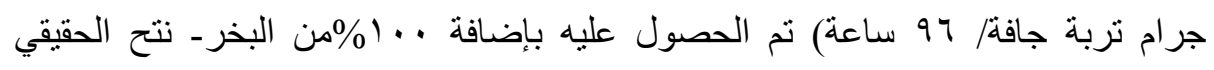

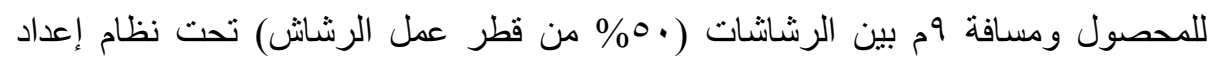

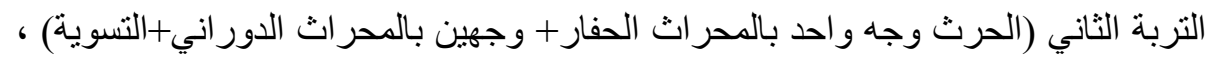

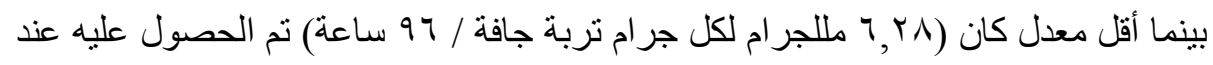

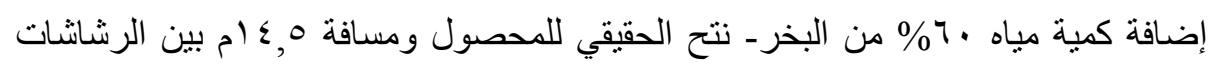

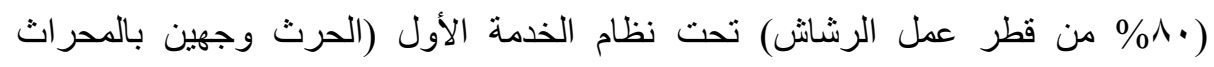



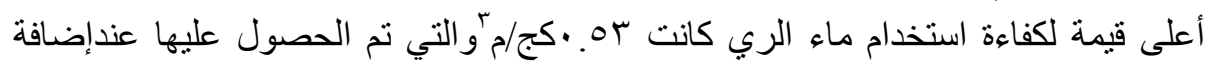

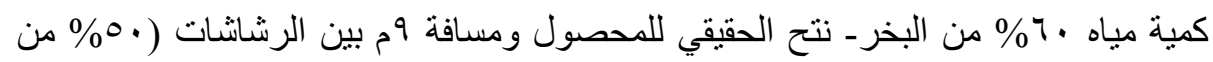






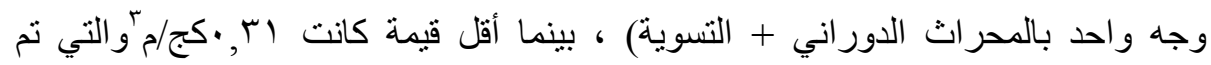



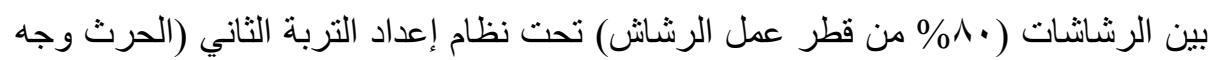

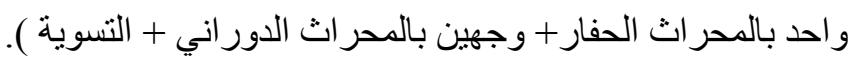

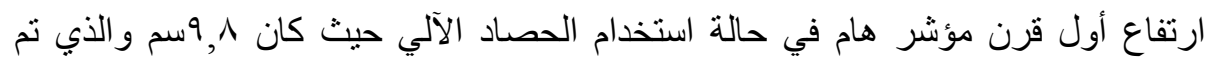

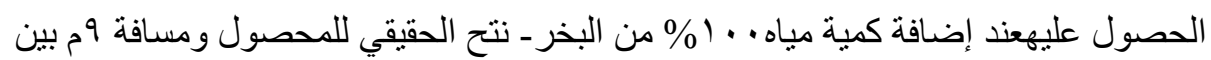

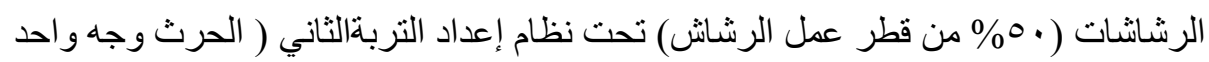

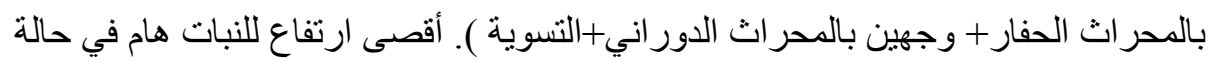



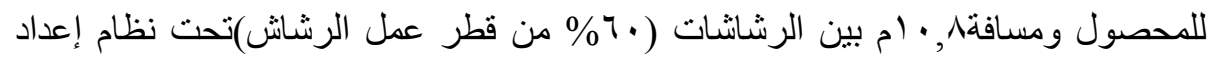
التربة الأول (الحرث وجهين بالمحر اث الحفار +التسوية ). 